образов, имеющих визуальное, аудиальное или кинестетическое представление, создается ребенком в процессе запоминания и воспроизводится им в дальнейшем.

Приведем пример. Старшим дошкольником было предложено для заучивания стихотворение «Подарки осени». На каждое слово или словосочетание рисовалось символическое изображение.

Ходит осень в нашем парке, («ходит» - рисуем ножки, «осень» - будет овал или буква «О», «в нашем парке»-лужок с деревьями)

Дарит осень всем подарки. («дарит» - рисуем открытые ладошки, «осень»-овал или буква «О», «всем подарки»- подарок с круглой стрелочкой вокруг)

Бусы красные - рябине, (рисуем бусы, лист рябины)

Фартук розовый - осине, (фартук розовый, лист осины)

Зонтик желтый - тополям, (зонтик желтый, лист тополя)

Фрукты осень дарит нам! (рисуем яблоки, груши, «осень» - овал или буква «О», «дарит нам» - ладошки и схематичное изображение человечков).

На этапе выбора стихотворения и создания ассоциативного ряда необходимо помнить о том, что модель, схема или таблица должны быть доступны для восприятия ребенка данного возраста. От этого зависит эффективность использования данного метода. Для детей младшего и среднего дошкольного возраста необходимо давать цветные мнемотаблицы, т.к. у детей остаются в памяти отдельные образы: цыпленок желтого цвета, мышка - серая, елочка - зеленая, ягодка - красная. А вот уже дети постарше могут справиться с черно-белыми схемами.

Дети, научившиеся работать с мнемосхемами, мнемотаблицами, приобретают навыки наглядного моделирования. Они учатся составлять рассказы, загадки, сказки любой сложности, соблюдая тематичность, логичность и последовательность.

Таким образом, можно сделать выводы, что, используя приёмы мнемотехники, мы значительно сокращаем время обучения детей связной речи. Анализируя и графически обозначая речевой материал (сказку, стихотворение и др.), дети под руководством педагога учатся зрительно воспринимать план речевого высказывания. Применение приёмов мнемотехники оказывает положительное влияние и на развитие неречевых процессов у детей: внимания, памяти, мышления.

$$
* * *
$$

1. Алексеева М.М., Яшина В.И. Методика развития речи и обучения родному языку дошкольников. - М.: Издательский центр «Академия», 2000. - 400 с.

2. Большева Т.В. Учимся по сказке. Развитие мышления дошкольников с помощью мнемотехники. СПб.: «Детство-Пресс»,2005. - 96 с.

3. Воробьева В.К. Методика развития связной речи у детей с системным недоразвитием речи. - М.: АСТ: Астрель: Транзиткнига, 2006. - 160 с.

4. Гурьева Н. А. Год до школы. Развиваем память: Рабочая тетрадь упражнений по мнемотехнике. Санкт-Петербург, 2000. - 198 с.

5. Полянская Т. Б. Использование метода мнемотехники в обучении рассказыванию детей дошкольного возраста: Учебно-методическое пособие. - СПб.: ООО Издательство «Детство- Пресс», 2009. - 64 с.

\title{
Ларин А.Н., Леонов Е.А. \\ Теоретические основы формирования саморегуляции поведения курсантов военного института войск национальной гвардии Российской Федерации
}

Пермский военньй институт войск начиональной гвардии (Россия, Пермь)

doi: $10.18411 / l j-31-10-2017-48$

idsp: 000001:lj-31-10-2017-48

Современные курсанты военного института войск национальной гвардии Российской Федерации - это, прежде всего, молодые люди. В классификации периодов 
жизни людей данный возрастной этап определяют как позднюю юность или раннюю зрелость. Отсутствие единого определения уже говорит о неоднозначности, сложности психологических особенностей данного жизненного периода курсантов. Именно на пору учебы приходится период активного жизненного и духовно-нравственного становления курсантов, максимума достигают в своем развитии не только его физические, но и психологические свойства. Этот возрастной этап максимально сензитивен для воспитания, обучения и профессиональной подготовки курсантов, когда активно формируется индивидуальный стильих деятельности. При этом курсанты более всего нуждаются в направляющей руке и верных ориентациях.

Организуя учебно-воспитательный процесс, необходимо активно и глубоко изучать характер воздействий на курсантов, определять тенденции развития личности и ее профессиональную направленность.

Специфика учебно-воспитательной деятельности в военном институте войск национальной гвардии РФ заключается в том, что педагогам приходится иметь дело с людьми особой категории, которые в дальнейшем, возможно, будут испытывать на себе влияние различных факторов: организованных и стихийных, осознанных и неосознанных. Поэтому тема формирования у курсантов саморегуляции поведения приобретает особую актуальность.

До сих пор в отечественных литературных источниках нет единой позиции по поводу понятия «саморегуляция поведения»:

- некоторые авторы используют термин - «психологическая настройка»;

- другие - «психогигиеническая саморегуляция»;

- третьи - «психофизическая саморегуляция»;

- четвертые предполагают использовать термин такого волевого качества как «самообладание»;

- пятые - «активная саморегуляция».

Наиболее распространенным термином является «саморегуляция», которым пользуются многие авторы.

И.В. Дубровина дает следующее определение саморегуляции: саморегуляция умение и навыки человека сознательно, преднамеренно, посредством применения разных методов и средств менять свое поведение, эмоциональное и физическое состояние, формировать позитивное эмоциональное отношение к выполнению заданий, связанных с риском [6].

Саморегуляция - это самостоятельное, без помощи из вне, управление личностью самой собой - считает С.В. Улыбин [9].

Л.Г. Дикой саморегуляция понимается как один из аспектов волевой подготовки[3].

Другое понятие дает А.Л. Гостюшин, где выделяет саморегуляцию как системноорганизованный процесс внутренней активности личности по инициации, выстраиванию, поддержанию и управлению различными видами и формами произвольной активности, которая непосредственно реализует достижение поставленных человеком целей [2].

Б.В. Зейгарник, А.Б. Холмогорова, Е.С. Мазурсчитают, что саморегуляция - это разные способы воздействия на собственное психическое состояние (и через него на прочие функции организма) путем использования,прежде всего, слов и соответствующих им мысленных образов [4].

Таким образом, в литературе не существуетодного взгляда по поводу определения саморегуляции поведения. 
Как известно, одной из специфических особенностей военной сферы является ее насыщенность разнообразными и ярко выраженными эмоциями, которые являются одной из форм отражения мира. Уровень эмоционального возбуждения в обыденной жизни находится в границах определенного ординара. В военном деле он может нарастать, а может оставаться на прежнем уровне. Организм как система существует среди окружающей природы только благодаря непрерывному уравновешиванию этой системы с внешней средой.

И.П. Павлов выделяет повышенную и неконтролируемую эмотивность. Физиологи под этим термином понимают нарушение равновесия между процессами возбуждения и торможения с преобладанием навязчивости возбуждения, что в той или иной мере дезорганизует деятельность курсантов, приводит к повышенной, но хаотической активности и снижению работоспособности. В этих случаях наблюдается заметное снижение мысленного контроля за выполняемыми действиями[8].

Все чувства, эмоции и эмоциональные состояния (удовольствие, радость, страх, боевое воодушевление и др.) проявляются в определенных переживаниях и характеризуются объективными особенностями реакций, заключающимися в комплексных изменениях деятельности различных внутренних органов, сердечнососудистой системы, характера дыхания, а также мимики, пантомимки, тембра голоса объективных признаков состояния психики. Кроме этого, происходят изменения в состоянии мышечного тонуса.

Исследования показывают, что отрицательные эмоциональные реакции всегда сопровождаются активизацией поперечно-полосатой мускулатуры, а расслабление мышц сопровождается внешними выражениями позитивных эмоций, состояния уравновешенности, покоя.

Неслучайно ряд приемов формирования саморегуляции поведения связан с упражнениями, направленными на произвольное изменение тонуса мышщ, с расслаблением различных групп мышц, с регуляцией дыхания. Дело в том, что изменение тонуса скелетных мышц, а также характера деятельности мышц, осуществляющих акт дыхания, имеет двойственную нервную регуляцию, из которых одна - произвольная, подчиняющаяся сознанию, управляемая высшими отделами мозга.

Помимо прямых нервных связей, проходящих от мозга к мышще, существуют обратные связи с корой головного мозга и с подкорковыми, нервными центрами.

Итак, курсант может управлять мышцами, а, следовательно, и регулировать интенсивность биотоков. Благодаря этому он способен влиять на свое состояние, помогать работе собственного мозга. Однако, далеко не все курсанты в должной мере владеют этим умением. Поэтому все активнее исследуются такие состояния как ожидание успеха, боязнь неудач, возникновение тревоги, регуляция эмоциональных состояний.

Многочисленные исследования в этой области позволили разработать средства, приемы сознательного управления своими эмоциями и поведением.

П.К. Анохин указывает, что развитию саморегуляции поведения способствует тихий спокойный голос, плавное музыкальное сопровождение, окраска помещения, температура воздуха[1]. Выполняя специально подобранные упражнения на напряжение и расслабление, дыхательные упражнения, имеется возможность воздействия на все составляющие эмоциональных реакций, а также и на характер эмоциональных переживаний. П.К. Анохин полагает, что это один из возможных путей преднамеренной саморегуляции эмоциональных состояний. Другой путь саморегуляции психических состояний связан с регулирующей и программирующей ролью слова. 
Слово, благодаря жизненному опыту курсанта, связано со всеми внешними и внутренними раздражителями, поступающими в большие полушария. Оно их заменяет и благодаря этому может вызвать все те действия, реакции, которые вызывают конкретные раздражители.

Вторая сигнальная система возникает на основе первой сигнальной системы и без нее существовать не может. Она действует только с первой сигнальной системой. Во взаимодействии они представляют физиологический механизм высшего, абстрактного мышления курсанта и его сознания (восприятие, память, воображение, привычки). Участие второй сигнальной системы в этих психологических процессах делает их сознательными.

Влияние слова на непроизвольные функции организма было многократно доказано и подтверждено. В частности, А.Р. Лурия назвал функцию речи одним из наиболее существенных средств регуляции человеческого поведения, поднимающего отдельные непроизвольные реакции до уровня сложных произвольных действий и осуществляющего контроль за протеканием высших, сознательных форм человеческой деятельности[7].

Разработанные идеи функциональной системы саморегуляции поведения дополнили Д.А. Леонтьев, Е.В. Эйдманидеей осознанности саморегуляции, идеей активного и осознающего свои задачи субъекта деятельности[5]. Таким образом, формирование осознаваемой курсантом цели является обязательным элементом и залогом успешности формирования саморегуляции поведения.

Подводя итог вышесказанному, можно констатировать, что саморегуляция поведения курсантов военного института войск национальной гвардии РФ представляет собой сложную многоуровневую систему психофизиологических процессов, происходящих в их организме, необходимую при выполнении любой деятельности, в т. ч.боевой подготовки. Саморегуляция поведения курсантов выступает как комплекс мероприятий, направленных на формирование у них психического состояния, способствующего наиболее полной реализации его потенциальных возможностей.

$$
* * *
$$

1. Анохин П.К. Принципиальные вопросы общей теории функциональных систем // Принципы системной организации функций. - М.: Наука, 2009. - С. 5 - 61.

2. Гостюшин А.Л. Энциклопедия экстремальных ситуаций. - М: Зеркало, 2015. - 251 с.

3. Дикая Л.Г. Психическая саморегуляция функционального состояния человека (системнодеятельностный подход). - М.: Издательство Института психологии РАН, 2013. - 318 с.

4. Зейгарник Б.В., Холмогорова А.Б., Мазур Е.С. Саморегуляция поведения в норме и патологии // Психологический журнал. - 2016. - № 4. - С. 122 - 132.

5. Ларин А. Н. К проблеме саморегуляции в процессе физической подготовки курсантов военных институтов войск национальной гвардии Российской Федерации. / А. Н. Ларин, А. В. Дубровский, В. П. Чердынцев // Журнал «Современные проблемы науки и образования». - 2016, № 6. URL: https://www.science-education.ru/ru/article/view?id=25794.

6. 6.Ларин А. Н. Моделирование саморегуляции поведения как средства повышения результативности физической подготовки курсантов военных институтов войск национальной гвардии Российской Федерации. / А. Н. Ларин, А. В. Дубровский // Мир образования - образование в мире.- 2017. -№1 (65). C 210-216.

7. Практическая психология образования / Под ред. Дубровиной И.В. - М: Сфера, 2013. - 592 с.

8. Ротенберг В.С., Бондаренко С.М. Мозг. Обучение. Здоровье.- М.: Просвещение, 2012. - 239 с.

9. Сильвачев С.В. Педагогические условия актуализации личностно-профессиональных ценностей курсантов в образовательном процессе военно-учебных заведений. Автореферат диссертации к. пед. н. - Хабаровск, 2013. -28 с.

10. Улыбин С.В. Динамика развития военно-профессиональной мотивации у курсантов военных институтов. Диссертация к. псих.н. - М., 2014. - 240 с. 